A Text-Book of West African Agriculture :

Soils and Crops. By Dr. F. R. Irvine. Pp. xiv + $348+32$ plates. (London : Oxford University Press, 1934.) 7s. $6 d$. net.

For an English doctor of science to write an agricultural text-book for native West African students can be no easy task, and only the West African reader can say how far Dr. Irvine has succeeded in his objects. The outlook of the African native towards soil science must, for example, be different from that of the European, and require a different mode of presentation from the teacher. Dr. Irvine has, however, succeeded in compressing into seventy pages a most lucid and simply expressed account of the essential points of soil science, and although this involves some degree of over-simplification, it always affords at least as adequate an explanation of fact and is as intelligible as the more orthodox point of view.

The main part of the book is devoted to descriptions of the cultivation of almost every crop that is or might be grown in West Africa, and should be of great value not only to the students of Achimota College, but also to all who wish to know the rudiments of tropical agriculture and economic botany. Dr. Irvine is cautious in recommending the adoption of modern European methods and implements into African agriculture, confining himself to descriptions rather than to praise of the achievements of more northerly civilisations. This is an excellent feature, and shows a deep understanding of the needs of the readers for whom the book is primarily intended, and by pointing out the virtues as well as the failings of the time-honoured systems of native agriculture gives the book an added value to the English reader.

The book is well produced and fully illustrated with plates and diagrams.

\section{Our Enemy the Termite}

By T. E. Snyder. Pp. xii +196. (Ithaca, N.Y. : Comstock Publishing Co., Inc., 1935.) 3 dollars.

THE author of this book has been associated, as an entomologist, with the U.S. Department of Agriculture since 1909. During this period he has been chiefly occupied with the investigation of termites, and other wood-destroying insects, and his original writings on these subjects are known to most entomologists. Much of the first-hand knowledge, thus acquired in an official capacity, is incorporated in a general way in this useful manual. The species of termites discussed are those native to the United States. While these 52 species represent only about 3 per cent of the world's termite fauna, the limitation is offset by the fact that most phases of termite biology are discussed. Dr. Snyder's book is, in fact, an authoritative introduction to the complexities of termite economy. The subjects of castes, reproduction, colony founding, growth, food, inquilines and other phenomena all come in for treatment.

The biological aspect of termite life is followed by chapters dealing with the relationship of these insects to man. The damage they bring about to buildings, crops and other property is well known, but relatively few people understand the ecological principles underlying effective control. Dr. Snyder has much to say on this subject; he is an advocate of the adoption of proper codes for building construction as a means for prevention, and explains the procedure to be adopted. The numerous clear illustrations, mostly taken from the author's published papers, add to the value of the book. While it is to be commended to the biologist, its clarity of style, and the addition of a glossary of unfamiliar terms, renders it easily understandable by the layman.

A. D. I.

\section{Weeds}

By Prof. W. C. Muenscher. (Rural Science Series.) Pp. xxii +577. (New York: The Macmillan Co., 1935.) 25s. net.

TRADE in plant products between widely separated countries has brought with it an interchange of the weeds of cultivated land. By the spread of Western civilisation to all parts of the world, there has resulted a preponderance of European weeds among the emigrants to other temperate regions. North America is no exception. A survey of this weed flora of the northern part of the United States shows that a large proportion of the adventive weeds are from Europe. The wide range of many weeds therefore renders a weed flora of more than local interest.

The problem of weed control is twofold, for it is necessary first to identify the plant concerned before it is possible to choose the most suitable means for destruction. Both of these-aspects of the problem are dealt with fully in this book. Chapters are devoted to agencies of weed dispersal, means of circumventing weeds, and weeds of special habitats. Mechanical and chemical methods of weed control are discussed in concise manner, but with sufficient detail to allow of their application by the practical farmer. Numerous references are given to modern research in this field. The bulk of the volume consists of a flora in which about five hundred weeds are described, suitable means of destruction being suggested for each. Many excellent line drawings, an artificial key to the species and a glossary should all increase the value of the work to the layman.

\section{Electron Diffraction}

By R. Beeching. (Methuen's Monographs on Physical Subjects.) Pp. viii + 108. (London: Methuen and Co., Ltd., 1936.) 3s. net.

THE increasing interest manifested in problems of surface and molecular structure is sufficient justif. cation for the appearance of this very clear and well-balanced little monograph, quite apart from the excellent practical illustration which it gives of the principles of wave mechanics. In the scope of a hundred pages, the author has discussed electron wave properties, the early history of the experimental side of the subject, diffraction by transmission and by reflection, apparatus and technique, and the principal types of problem suited to investigation by electron diffraction. The book may be strongly recommended as a most useful review of the subject. A. F. 